\title{
Analysis of the Model of Assistance for Children Who Are Dealing with Law in the Child Protection Institution (LPA) in Bima City
}

\author{
Z Zuhrah \\ Law Studies Program \\ Muhammadiyah Bima School of Law \\ Bima, Indonesia
}

\author{
Muhammad Asad Imaduddin \\ Law Studies Program \\ Muhammadiyah Bima School of Law \\ Bima, Indonesia
}

\author{
Husnatul Mahmudah* \\ Law Studies Program \\ Muhammadiyah Bima School of Law \\ Bima, Indonesia \\ zhoemachy@gmail.com
}

\author{
J Juhriati \\ Law Studies Program \\ Muhammadiyah Bima School of Law \\ Bima, Indonesia
}

\author{
M Amin \\ Law Studies Program \\ Muhammadiyah Bima School of Law \\ Bima, Indonesia
}

\begin{abstract}
This study aims to analyze the model of mentoring for children in conflict with the law carried out by LPA in Bima city. Researchers want to map out the model of mentoring for children so that in the long term it can be disseminated and become good practices that can be adopted by other regions or other institutions that focus on issues concerning children. This study used a qualitative method with a sociological approach. The data collection method used was interview, documentation and focus group discussion (FGD) techniques. The data analysis technique used three stages, namely data reduction, data display, conclusion and verification. The results of this study indicate that in handling children facing the law, the Bima City Child Protection Agency applies a community-based mentoring model. This mentoring model uses three stages of activities: (1) prevention by involving the family, school and community, this activity is carried out in the form of direct socialization at school and touching the general public by involving mass organizations and communities by interacting directly with children, also this activity takes the form of socialization in schools and communities ; (2) the goal is to strengthen the family by providing parenting education to better understand and understand in dealing with children who are faced with the law ; and (3) development which is intended to deal with children who are facing the law, which cannot be resolved through diversion. Assistance to children in addition to being a form of implementation of the mandate of the Law is also a form of community responsibility to create the best future generations. Thus, through this research, the mapping of the mentoring model carried out by LPA Kota Bima can be a reference in properly handling child cases.
\end{abstract}

\section{Keywords—model, handling of ABH, LPA Bima}

\section{INTRODUCTION}

It seems that children who are involved in legal matters of a serious nature are the center of attention and concern of all circles. In 2002, when President Megawati Soekarnoputri ratified Law Number 23 of 2002 concerning Child Protection. Then in 2003 followed by the formation of the Indonesian Child Protection Commission (KPAI) which is based on Law number 23 of 2002. In 2004, Law Number 23 of 2004 concerning the Elimination of Domestic Violence
(PKDRT) was formed, where children are also part of victims of domestic violence that occur in the community. If we look at the history of the formation of Law Number 23 of 2002 and the formation of the KPAI in 2003, it shows that cases of children who are faced with the law are becoming increasingly worrying for all circles.

Children who face the law are categorized into two behaviors. First, offense status, namely all deviant children's behavior such as running away from home, skipping school, disobeying, and the like which constitutes a child's delinquency, and if the behavior is carried out by an adult it will be considered not a crime. Second, juvenile delinquency as a criminal act is delinquency behavior of children which is determined as an act against the law or a crime [1].

Nowadays, the phenomenon of children dealing with the law is increasing. This phenomenon is quite diverse and complex. Among them are children as victims and witnesses and children as perpetrators. The variety and complexity of child cases include cases of sexual violence, theft cases, drug cases and many other cases. So that this is a common concern. Nationally, even though Indonesia has ratified the Convention on the Rights of the Child from the United Nations for 20 years, it does not mean that cases of violence against children have decreased. [2] In Bima in particular, in the last three years, the increase in cases of children was quite high. Based on case reports in 2016 there were 86 cases of children, in 2017 there were 108 cases of children detected and entered at the Bima City Police. Meanwhile, in 2018 it also increased to 116 cases.

Children who are faced with the law must get attention as a form of concern and advocacy efforts to restore the psychological effects caused by the various incidents they have experienced. Fear and trauma can become psychological disorders for children so that a comfortable and calm atmosphere must be created, and that can be done through mentoring. Even when faced with the law, both as perpetrators, victims and children as witnesses, the principle of the best interests of the child remains to be 
prioritized. This is because children are a vulnerable group that should get special attention [4].

Children who experience psychological trauma need the active role of various elements including the Child Protection Agency (LPA). As an extension agent of the Indonesian Child Protection Commission (KPAI), LPA is an organ that focuses on child protection where one of its duties is to ensure children have fulfilled their basic rights, namely the right to life, growth and development, the right to protection and the right to participate. The height of the problem of children is an important concern for all parties, so it is necessary to ensure that the selection of a model for assisting cases of children facing the law is right on target. So that children who have been caught in cases are no longer recidivists and at least no longer add to the number of increases in the case of Children in Conflict with the Law $(\mathrm{ABH})$.

Departing from this problem, LPA Bima encourages the resolution of various cases of Children Facing the Law to be resolved outside the trial or diversion. Restorative justice will be achieved if the best interests of the child, which is the basic principle of child protection, can be prioritized in resolving the problem of Children with the Law. In its implementation, the concept of restorative justice must work in synergy between parents, schools, the community, and law enforcement officials. [5] The child mentoring model applied in LPA Bima seeks to direct restorative justice through various efforts such as preventive; reintegrative and promotive.

\section{METHODS}

This research dealing with the law in LPA located in Bima city. This research employed qualitative research methods that emphasize participation and in-depth data mining in the process. Data collection in this study was carried out by in-depth interviews, focus group discussions, and documentation. This in-depth interview is necessary to find out the experience and process of mentoring carried out. This type of research is field research with a qualitative approach method, namely scientific research that emphasizes the scientific character of the data source, [6] where the results of this research are descriptiveanalysis in the form of written or spoken words of the observed behavior, especially related to the Child Faces Assistance Model. Law in LPA Bima city.

Data collection and analysis method, desk study, in the form of policy review, this is intended to see policies that are authorized to deal with children in conflict with the law, and the principle of the best interests of children in making these policies. The field of study is an analysis of children's involvement in case handling and assistance by LPA Bima. Focus group discussion, is used to explore information on perspectives and opinions related to the problems described in this study. This FGD is devoted to LPA Bima so we can ascertain what models are often used in mentoring children. The interview was intended to deepen information from the LPA Kota Bima, local government, police, and related agencies. Site visits and observations at research locations to get a more complete understanding.

The data analysis technique in this study was carried out through several stages which are data reduction, namely the process of selecting and focusing the data obtained from the field, data display, which is grouping data based on problems to see patterns and relationships between collected data then draw conclusions and verify data [7].

\section{RESUlT AND DISCUSSION}

Based on the results of research that has been done, the implementation of assistance for Children with Laws (ABH) at the Child Protection Institution (LPA) in Bima City has its characteristics to meet the best interests of children. Researching the field, a model was found by LPA in Bima city as an effort to minimize the number of $\mathrm{ABH}$ cases in the City of Bima. First, preventive efforts, this is carried out by LPA Bima in collaboration with several government agencies such as the DP3AP2KB Office (Office for Women's Empowerment, Child Protection, Population Control and Family Planning), Bima City Police, and several community organizations (Ormas) that focus on is engaged in child protection issues. Some of these mass organizations are, Nasyiatul Aisyiah, Muslimat NU, and Aisyiyah. Besides that, it also involves the PKK both at the regional level and in each sub-district. This is intended so that awareness of child protection is understood by all parties. So that child protection is not only understood by law enforcers. However, the general public should also understand and be actively involved in child protection.

The preventive efforts carried out by LPA in Bima city are shown in the socialization activities which are quite intensive and measurable. This outreach activity contains materials about children who are involved in criminal acts, both as perpetrators, victims and witnesses. The material is intended to provide preliminary knowledge to children, parents or parties closer to children so that they are always aware of threats that can interfere with children's development, both mentally and physically. This outreach activity was carried out in (1) schools in Bima City, ranging from early childhood, elementary, junior high to high school; (2) Qur'anic Education Park and Playgroup; (3) communities that involve children as members (such as the Mbojo Tana'o literacy community).

First, prevention is intended as an effort to break the chain of aspects that harm children's development. Like violence against children and child delinquency, in psychological studies it is the impact of the activities of adults around them, thus affecting the child's personalit [8]. Therefore, the prevention efforts carried out by LPA in Bima city also target parents and the community around children who are influential in their growth and development.

Second, reintegrative efforts. Strengthening in this case is intended so that the parties close to the child can play a maximum role in the child's social life and emotional development. The role of parents in this matter has a very big effect. In addition to childcare obligations, parents can also play a role in monitoring the child's growth and 
development. [9] Family and social environment is one of the factors that triggers high juvenile delinquency and $\mathrm{ABH}$ rates. In addition, individual interactions in friendships can also affect children's psychological development [10]. Therefore, LPA in Bima city seeks to encourage the family and society in general to support the development and growth of children positively, avoid violence and intimidation for children. This reintegrative effort is intended to reduce the factors that make families vulnerable to negative behavior. Besides, it is also a forum for sharing information about parenting (for parents) and healthy associations (for children and adolescents) [11].

Third, development efforts (promotive). This activity is intended for children who are involved in solving legal cases through litigation. In terms of children's psychological development, law enforcement processions often have an unfavorable impact. Children can experience deep trauma if they are unable to control themselves in the ABH case. This development effort is more participative, where the nuclear family and the community take a role in strengthening children mentally. This activity must also be sustainable and as social control. LPA in Bima city does not only focus on handling cases that are resolved through legal channels, but also through strengthening the role of the community as a function of social control for children. Often children who are faced with the law do not get a good place in social life. In other words,

Apart from the three things mentioned above, LPA in Bima city also has a flow and procedure in assisting and handling $\mathrm{ABH}$ cases. The flow of case assistance is as follows by Fig. 1 .

Flow of Case Handling For LPA in Bima City

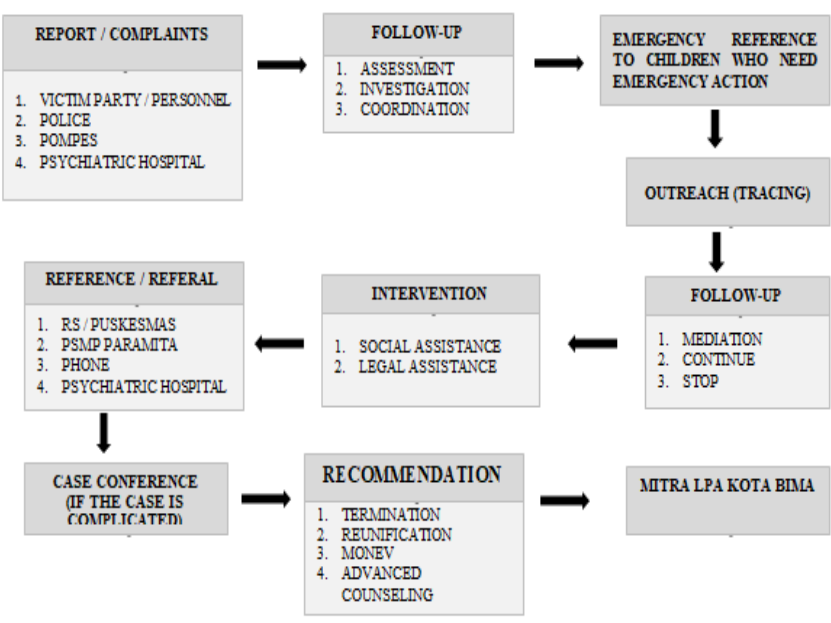

Fig. 1. Flow of Case Handling for LPA in Bima City

LPA in Bima city is an institution that is under the vertical command of the mayor where several policies in handling $\mathrm{ABH}$ are also influenced by regulatory policies, laws, regional regulations, regional regulations, and so on.

LPA in Bima city providing assistance often comes from reports from the community and victims. So it is not uncommon for assistance activities to be carried out when a case comes in. Based on the results of the study, the $\mathrm{ABH}$ number that occurred in the city of Bima continued to increase every year. In 2017 there were 76 cases, in 2018 there were 84 cases, and in 2019 there were 87 cases. Meanwhile, in 2020, until June there were 44 cases of ABH who were being accompanied by LPA in Bima city. Several cases of Children Dealing with the law can be classified based on several types of cases, as Fif. 2 below.

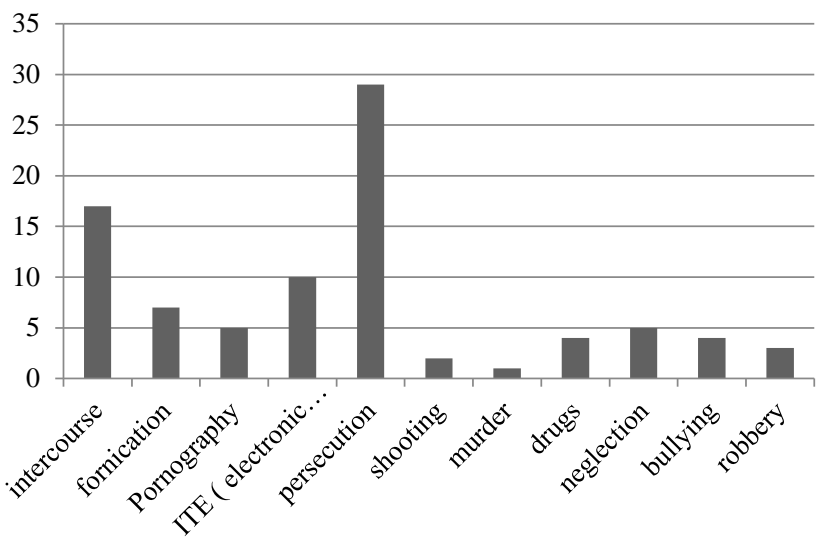

Fig. 2. Types of Criminal Acts ABH in Bima (2019)

Meanwhile, if you look at the location or place of violence or various other cases related to the child with the law, it is not far from (1) the family environment; (2) education / school; (3) public places (on the market or the street); and (4) tourist attractions. From the data above, it is known that children who are faced with the law are not only victims, but often as perpetrators of crimes or who commit acts against the law. LPA in Bima city will provide assistance to incoming cases. Anyone can report any activity that is detrimental to children's rights, either the victim, the perpetrator, or the witness. The general public can also report to the police at the PPA unit.

Furthermore, LPA in Bima city will conduct an assessment of the existing cases, with the aim of obtaining further information and ascertaining the actual conditions and events. Furthermore, investigations and coordination are carried out with other parties such as the police in order to clarify the status of the case, whether the elements are fulfilled to be resolved at the legal table or not. Based on the results of the assessment, investigation and coordination, the case can be concluded to continue the form of settlement through litigation or non-litigation channels. Referring to the Convention on the Rights of the Child, that all activities related to children must refer to the principle of goodness for children. So that based on Law Number 11 of 2012 concerning the Juvenile Criminal Justice System that if a case can be resolved by deliberation and / or mediation, then the best way is through mediation. Or at least do a diversion. The next stage is the determination of intervention actions in case assistance. In child case assistance activities, actions that are quite energy-draining are social assistance and legal assistance. Social assistance is intended to restore a child's good name, as well as a form of trauma healing to children's mental health and children's self-confidence. actions that drain energy, namely social assistance and legal assistance. 
Social assistance is intended to restore a child's good name, as well as a form of trauma healing to children's mental health and children's self-confidence. actions that drain energy, namely social assistance and legal assistance. Social assistance is intended to restore a child's good name, as well as a form of trauma healing to children's mental health and children's self-confidence.

\section{CONCLUSION}

Based on the description above, it is known that the model of mentoring children who is dealing with Laws in LPA located in Bima city is community-based assistance that leads to efforts to realize restorative justice (restorative justice). This community-based assistance was carried out by LPA in Bima city by implementing several stages. First, preventive efforts, namely carrying out various direct socialization activities in collaboration with various community organizations, communities that are in direct contact with children. Second, efforts to strengthen (reintegrative) where LPA in Bima city conducts intensive communication with parents of children who are dealing with the law, to strengthen parenting and mental development and children's social life. Third, development, namely efforts to assist cases through legal channels that are not resolved by diversion.

Child protection is not only the responsibility of the government agency or agency concerned. However, the entire community must also take a role in child protection and strive to minimize children who come into contact with the law. The community-based $\mathrm{ABH}$ assistance model such as that carried out by LPA in Bima city can be an alternative in overcoming the high number of children who are dealing with the law.

\section{REFERENCES}

[1] Jafar, Kamaruddin. "Restorative Justice Atas Diversi Dalam Penanganan Juvenile Deliquency (Anak Berkonflik Hukum)." Al-'Adl 8.2 (2015): 81-101.

[2] Sumy Hastry Purwanti, Violence against Children and Women from the Perspective of Medical and Forensic Sciences, Jakarta: Rayyana Komunikasindo, 2017

[3] Annual Report of the PPA Unit of the Bima City Police for 2018

[4] Lefaan, Vilta Biljana Bernadethe, and Yana Suryana. Review of Legal Psychology in Child Protection. Deepublish, 2018.

[5] Judge, Zulfikar. "The Implementation of Children in Confronting Law Policies in Support of Law and Human Rights Development at the West Jakarta Police." Lex Jurnalica 10.3 (2013): 18039.

[6] Lexy J. Moleong, Qualitative Research Methodology, Bandung: PT Remaja Rosda Karya, 2002.

[7] Miles, Huberman, and A. Michael Huberman. "Qualitative Research Methodology." Jakarta: Sinar Media (1992).

[8] Al Adawiah, Rabiah. "Efforts to Prevent Violence Against Children." Journal of National Security 1.2 (2015): 279-296.

[9] Holland, Sally. Child and family assessment in social work practice. Sage, 2010.

[10] Davies, Douglas. Child development: A practitioner's guide. Guilford Press, 2010

[11] Hasanah, Uswatun, and Santoso Tri Raharjo. "Community based handling of child violence." Share: Social Work Journal 6.1 (2016) 